\title{
ANALYSIS OF LEDGER-STAND JOINTS IN THE ALUMINUM MODULAR SCAFFOLD
}

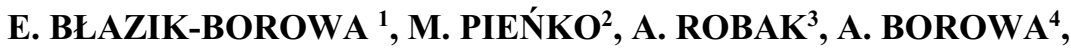 \\ P. JAMIŃSKA-GADOMSKA ${ }^{5}$
}

\begin{abstract}
This paper concerns an approach to model the ledger-stand joints of modular scaffolds. Based on the analysis of the working range of the ledger (represented by a linear relationship between load and displacement), two models of the ledger-stand joint are analysed: first - with flexibility joints and second - with rigid joints and with a transition part of lower stiffness. Parameters are selected based on displacement measurements and numerical analyses of joints, then they are verified. On the basis of performed research, it can be stated that both methods of joint modelling recommended in this paper, can be applied in engineering practices.
\end{abstract}

Keywords: modular scaffolding, laboratory test, joints flexibility, statistical analysis, static scheme of ledger

\section{INTRODUCTION}

One type of scaffolding is the modular scaffold. Scaffolds of this type are assembled from single elements, such as base jacks, ledgers, stands, bracings, and platforms. Additionally, scaffoldings are designed in a way that allows the model to create spatial structures of any shape. It enables

\footnotetext{
${ }^{1}$ Prof., PhD., Eng. Lublin University of Technology, Faculty of Civil Engineering and Architecture, Nadbystrzycka 40 str., 20-618 Lublin, Poland, e-mail: e.blazik@pollub.pl

${ }^{2}$ M.Sc., Lublin University of Technology, Faculty of Civil Engineering and Architecture, Nadbystrzycka 40 str., 20-618 Lublin, Poland, e-mail: m.pienko@pollub.pl

${ }^{3}$ M.Sc., Lublin University of Technology, Faculty of Civil Engineering and Architecture, Nadbystrzycka 40 str., 20-618 Lublin, Poland, e-mail: a.robak@pollub.pl

${ }^{4}$ Student, Jagiellonian University in Kraków, Faculty of Mathematics and Computer Science, S. Łosiewicza 6 str., 30-348 Kraków, Poland, e-mail: ada.borowa@gmail.com

${ }^{5}$ M.Sc., Lublin University of Technology, Faculty of Civil Engineering and Architecture, Nadbystrzycka 40 str., 20-618 Lublin, Poland, e-mail: p.jaminska@pollub.pl
} 
constructing scaffolds around facilities of complicated shapes, e.g. historical monuments $[13,16]$ or in industrial facilities. Currently, development of modular scaffolds is based on the introduction of aluminium as a construction material of the scaffold components. Due to the application of aluminium, a scaffold becomes lighter. On the other hand, it causes technological problems concerning e.g. combining different types of materials and then modelling these combinations. In the case of aluminium scaffolds, it shall be tested whether a linear-elastic material can be used in its numerical model, and, if so, in what range of load capacity. Joint flexibility should also be determined as in the case of all other scaffolds.

The analysis of joint flexibility, made of various materials and used in different types of constructions, is currently the subject of many written works. The reviews of models, which describe behaviours of steel frame joints, are included in such papers as [3, 10]. Paper [5] is devoted to computer analysis of steel-concrete joint flexibility. Numerical models considering the complicated geometry of joints, nonlinear material characteristics, as well as such nonlinear phenomena as contact and friction between connected components, are presented in this paper. Laboratory tests, apart from numerical analysis of steel joints, are demonstrated in work [8]. A similar scope of research for a steel-concrete joint is shown in work [6] and its results have provided the basis for preparation of practical remarks on shaping and designing composite joints. Papers [9, 17] present different stiffness matrices of beam elements, taking into account the flexibility of connections to a joint, and, subsequently, model verification is demonstrated via the example of single- and multi-storey frames. The problem of joint flexibility in scaffolds is particularly important. Papers $[1,7,11,15]$ are solely or partially devoted to this issue. Articles [12] and [18] show laboratory tests on the flexibility of various scaffold joints. In paper [11] it is demonstrated that the consideration of flexibility in the case of scaffolds influences the calculation time and the obtained results. Paper [1] is an overview study presenting the information on both issues: flexibility research as well as the use of its results in static-strength analyses on scaffolds. Nevertheless, the rest of papers [7] and [15] refers to research on joint flexibility and static-strength analysis of the complete scaffold, considering the results of laboratory tests.

This paper demonstrates the analysis of laboratory measurements of displacements in the middle of aluminium ledgers caused by a concentrated force and a uniformly distributed load. On the basis of this research, the linear-elastic nature of working range of ledger determined. Subsequently, for this scope of work, the model of a stand-ledger joint is analysed. The obtained results are verified on the basis of measurements of o-ledgers displacements caused by a distributed load and double o-ledgers loaded with a concentrated force. This work stands out from previously mentioned ones since joint 
flexibility is determined on the basis of tests made on the whole ledger, in contrast to the research made only on the joint itself, as has been presented so far.

\section{LABORATORY RESEARCH}

\subsection{DESCRIPTION OF PROCEDURES AND A TEST STAND}

The research objects were ledgers of the ALUROTAX system with a cross-section $\phi 48.3 \mathrm{~mm} \times 4 \mathrm{~mm}$, as well as double o-ledgers, with additional rectangular pipes of dimensions $40 \mathrm{~mm} \times 20 \mathrm{~mm}$ and a wall thickness of $3 \mathrm{~mm}$. The main parts of the ledgers are made of aluminium and ledger ends are made of steel. Table 1 summarizes the types of ledgers that have undergone laboratory tests and the number of trials carried out for each test.

Table 1. The summary of o-ledgers types and test types.

\begin{tabular}{|c|c|c|c|c|c|c|}
\hline $\begin{array}{l}\text { Element } \\
\text { type }\end{array}$ & Name & $\begin{array}{l}\text { Element } \\
\text { length } \\
L[\mathrm{~mm}]\end{array}$ & $\begin{array}{l}\text { No. of test } \\
\text { with } \\
\text { concentrated } \\
\text { force }\end{array}$ & $\begin{array}{l}\text { No. of tests with } \\
\text { uniformly } \\
\text { distributed load }\end{array}$ & $\begin{array}{c}\text { Distance between } \\
\text { pulley blocks } l \\
{[\mathrm{~mm}]}\end{array}$ & $\begin{array}{l}\text { No. of } \\
\text { pulley } \\
\text { blocks }\end{array}$ \\
\hline \multirow{6}{*}{ o-ledger } & o-ledger $0.732 \mathrm{~m}$ & 732 & 5 & 5 & 183 & 3 \\
\hline & o-ledger $1.088 \mathrm{~m}$ & 1088 & 5 & 5 & 181 & 5 \\
\hline & o-ledger $1.572 \mathrm{~m}$ & 1572 & 5 & 5 & 196 & 7 \\
\hline & o-ledger $2.072 \mathrm{~m}$ & 2072 & 5 & 5 & 259 & 7 \\
\hline & o-ledger $2.572 \mathrm{~m}$ & 2572 & 5 & 5 & 285 & 8 \\
\hline & o-ledger $3.072 \mathrm{~m}$ & 3072 & 5 & 5 & 340 & 8 \\
\hline \multirow{5}{*}{$\begin{array}{c}\text { double } \\
\text { o-ledger }\end{array}$} & double o-ledger $1.088 \mathrm{~m}$ & 1088 & 5 & - & 181 & - \\
\hline & double o-ledger $1.572 \mathrm{~m}$ & 1572 & 5 & - & 196 & - \\
\hline & double o-ledger $2.072 \mathrm{~m}$ & 2072 & 5 & - & 259 & - \\
\hline & double o-ledger $2.572 \mathrm{~m}$ & 2572 & 5 & - & 285 & - \\
\hline & double o-ledger $3.072 \mathrm{~m}$ & 3072 & 5 & - & 340 & - \\
\hline
\end{tabular}

Laboratory tests were performed on the Zwick-Roell test machine. The measuring range of the device is $\pm 3000 \mathrm{kN}$. The range of piston movement is up to $60 \mathrm{~cm}$. The accuracy of force and displacement measurements corresponds to a voltage of $2 \mathrm{mv} / \mathrm{V}$. Both o-ledgers (Fig. 1, Fig. 2a) and double o-ledgers (Fig. 2b) were mounted to steel base jacks placed on a threaded steel pivot $38 \mathrm{~mm}$ in diameter. Due to this fact, the stiffness of the vertical elements was considerably greater than the stiffness of the tested element. The pivots welded to the steel angles were screwed into the test 
machine base. One of the pivots was screwed with a moment that guarantees obtaining pinned support, whereas the other one can slide within the base rails (Fig. 2c).

a)

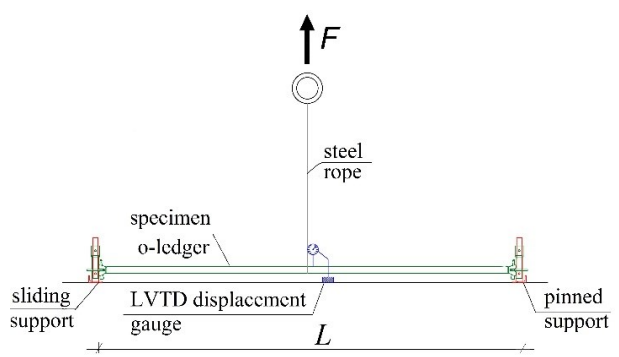

b)

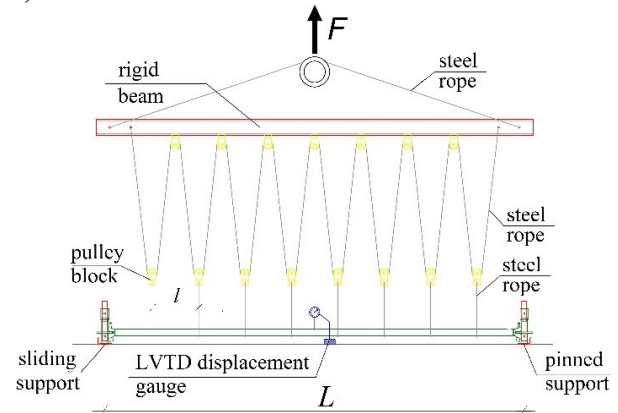

Fig. 1. The scheme of the test stand for measurements of the load-displacement relation under: a) concentrated force, b) uniformly distributed load.

a)

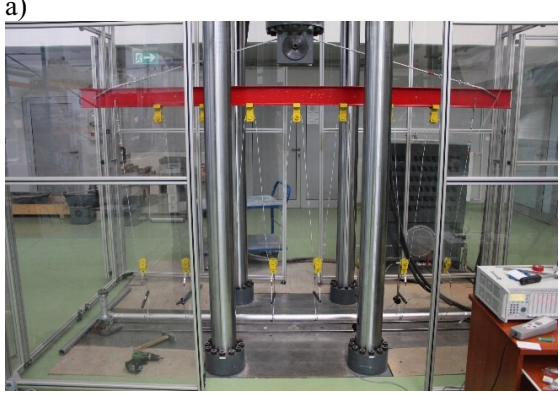

b)

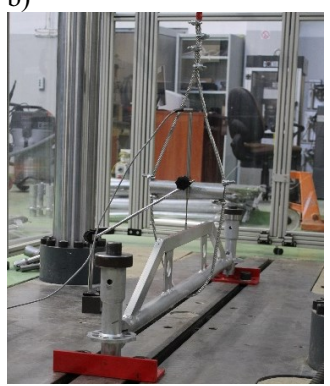

c)

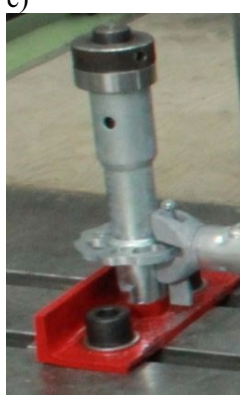

Fig. 2. The test stand for measurements of the load-displacement relation: a) o-ledger, b) double o-ledger, c) connection of the ledger and stand.

A load in the form of a concentrated force was implemented by a steel rope placed in the middle of the o-ledger. The action increment of the load was controlled by displacement and was equal to 5 $\mathrm{mm} / \mathrm{min}$. Since the steel rope was subjected to considerable extension during research, the displacement of crosshead recorded by the test machine was not reliable, thus an additional LVTD displacement gauge was applied. In the case of tests under a distributed load, a system of blocks and steel ropes was applied to distribute loads evenly over the length of the ledgers. As shown in the case of research performed for the concentrated force, the additional LVTD displacement gauge was also used for the distributed load. For both types of load, the relationship between force on the 
test press crosshead and ledger displacement in its mid-span was measured. Sample results of measurements are shown in Fig. 3.

a)

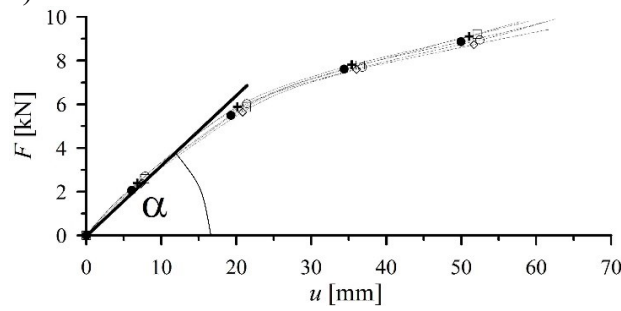

b)

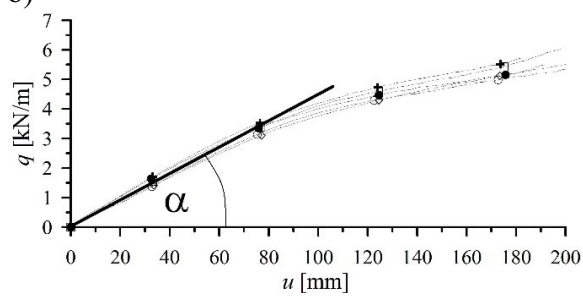

c)

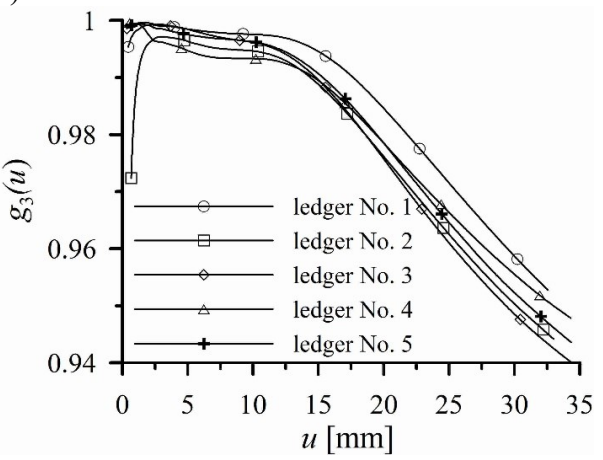

Fig. 3. The measurements results of force versus displacement for: a) o-ledger with length of $1.572 \mathrm{~m}$ loaded with concentrated force $F, \mathrm{~b}$ ) o-ledger with length of $2.572 \mathrm{~m}$ loaded with uniformly distributed load $q, \mathrm{c}$ ) functions $g_{3}(u)$ for o-ledger with length of $1.088 \mathrm{~m}$.

\subsection{ANALYSIS OF MEASUREMENT RESULTS}

The analysis of joint flexibility is proceeded by determination of the displacement range, for which it can be assumed that the system works linearly, and ledger behaviour can be described similarly, meaning that the linear equation has to be determined to approximate the results of measurements in this area. In relation to this, after visual analysis of the results, the approximation of measurements is conducted by two functions: a linear function and a polynomial one. A linear range is selected on the basis of local maxima of function $g_{3}(u)$ or chosen manually after graph analysis of function $g_{3}(u)$, e.g. for an o-ledger of $1.088 \mathrm{~m}$ in length (Fig. 3c). Function $g_{3}(u)$ is described by the formula:

$$
g_{3}(u)=2 \frac{\rho_{p}^{2}(u) \rho_{w}^{2}(u)}{\rho_{p}^{2}(u)+\rho_{w}^{2}(u)},
$$

where: 
$\rho_{p}^{2}(u)$ - correlation coefficient square for a straight-line, approximating the first part of measurement results (Fig. 3), $\rho_{w}^{2}(u)$ - correlation coefficient square for a polynomial, approximating the second part of measurement results.

After analysing element behaviour during the tests and determining two functions, approximating the load-displacement relationship, i.e. a linear function and a polynomial, a static analysis of results can be performed in accordance to standard EN 12811-3 [4]. The determination of the linear-elastic part of the graph force versus displacement requires determining the tangent of the angle of straight-line inclination, which is referred to in the article as the superelement stiffness $K_{e}$. Calculations of this value are performed according to the procedure for joints given in standard EN 12811-3 [4]. The following formulae are used for:

- $\quad$ average value

$$
\bar{k}=\frac{n}{\sum_{i=1}^{n} \frac{1}{k_{i}}},
$$

where:

$k_{i}=\tan (\alpha)-$ stiffness value of $i$-th element and simultaneously a directional coefficient of a straight-line, approximating the first part of measurement results,

- standard deviation

$$
\sigma_{k}^{2}=\frac{1}{n} \sum_{i=1}^{n}\left(k_{i}-\bar{k}\right)^{2}
$$

- variation coefficient

$$
v_{k}=\frac{\sigma_{k}}{\bar{k}}
$$

Finally, the superelement stiffness is determined from the formula:

$$
K_{e}=\mu \bar{k},
$$

where: $\mu=1.0$ at $v_{k} \leq 0.10, \mu=0.9$ at $0.10<v_{k} \leq 0.20, \mu=0.8$ at $0.20<v_{k} \leq 0.30, \mu=0.7$ at $0.30<v_{k} \leq 0.40$, and at $0.40<v_{k}$ the tests should be repeated. 
The results of calculations are compiled in Table 2 and Table 3. Column 2 shows the values of superelement stiffness and column 3 demonstrates coefficients $v_{k}$. In these tables, in the $4^{\text {th }}$ column, there are also the coordinates of a point between a linear function and the polynomial. The abscissa of this point is defined as the lowest value among all $u_{i}$ values, ending the parts of graphs approximated by a linear relationship. The last columns of Table 2 and Table 3 contain the maximum specified permissible loads for ledgers, obtained from the procedure described in standard [4] and paper [2]. These values are calculated through the following steps: determination of the maximum value (the ultimate value) $r$, calculation of $y_{i}=\ln r$, determination of average value $\bar{y}$ and standard deviation $\sigma^{2}$, determination of the lower $5 \%$-quantile $y_{5}=\bar{y}-2.46 \sigma$, determination of the limited basic characteristic resistance $R_{k, b}=e^{y_{5}}$, determination of factor $\gamma_{R 2}$ from the equation:

$$
1.25 \geq \gamma_{R 2}=-0.025 \bar{q}_{e}+1.275 \geq 1.00,
$$

determination of the nominal characteristic value of resistance from the formula:

$$
R_{k, n o m}=R_{k, b} / \gamma_{R 2}
$$

and calculation of the specified permissible value of the tested parameter $(F$ or $q$ )

$$
R=R_{k, n o m} / \gamma_{M} \gamma_{F}
$$

where:

$\bar{q}_{e}$ - average value of the ratio of the plastic and elastic energy [2], $\gamma_{M}=1.1, \gamma_{F}=1.5-$ partial safety factors.

Table 2. The measurement results of displacements in an elastic range caused by concentrated force $F$.

\begin{tabular}{|c|c|c|c|c|c|}
\hline \multirow{2}{*}{$L[\mathrm{~m}]$} & \multirow{2}{*}{$K_{e}^{F}[\mathrm{kN} / \mathrm{mm}]$} & \multirow{2}{*}{$v_{k}[/]$} & The linear part of graph $F-u$ & \multirow{2}{*}{$F[\mathrm{kN}]$} \\
\cline { 4 - 5 } & & $u_{\text {min }}[\mathrm{mm}]$ & $F_{l}=K_{e}^{F} u_{\min }[\mathrm{kN}]$ & \\
\hline \multicolumn{7}{|c|}{ o-ledger } \\
\hline 0.732 & $1.0 \cdot 2.060=2.060$ & 0.069 & 5.88 & 12.11 & 7.31 \\
\hline 1.088 & $1.0 \cdot 0.835=0.835$ & 0.074 & 7.50 & 6.26 & 4.22 \\
\hline 1.572 & $1.0 \cdot 0.313=0.313$ & 0.045 & 9.34 & 2.92 & 2.95 \\
\hline 2.072 & $1.0 \cdot 0.143=0.143$ & 0.089 & 20.47 & 2.93 & 2.42 \\
\hline 2.572 & $1.0 \cdot 0.0735=0.0735$ & 0.045 & 46,52 & 3.42 & 2.10 \\
\hline 3.072 & $1.0 \cdot 0.0466=0.0466$ & 0.048 & 62.59 & 2.92 & 2.01 \\
\hline \multicolumn{7}{|c|}{ double o-ledger } \\
\hline 1.088 & $0.8 \cdot 4.966=3.973$ & 0.236 & 1.30 & 5.16 & 14.67 \\
\hline 1.572 & $0.9 \cdot 3.376=3.038$ & 0.118 & 2.59 & 7.87 & 12.51 \\
\hline 2.072 & $1.0 \cdot 1.296=1.296$ & 0.013 & 2.61 & 3.38 & 8.56 \\
\hline 2.572 & $1.0 \cdot 0.795=0.795$ & 0.026 & 4.08 & 3.24 & 7.56 \\
\hline 3.072 & $1.0 \cdot 0.453=0.453$ & 0.077 & 7.48 & 3.39 & 5.49 \\
\hline
\end{tabular}


Table 3. The measurement results of displacements in an elastic range caused by distributed load $q$.

\begin{tabular}{|c|c|c|c|c|c|}
\hline \multirow{2}{*}{$L[\mathrm{~m}]$} & \multirow{2}{*}{$K_{e}^{q}\left[\frac{\mathrm{kN} / \mathrm{m}}{\mathrm{mm}}\right]$} & \multirow{2}{*}{$v_{k}[/]$} & \multicolumn{2}{|c|}{ The linear part of graph $q-u$} & \multirow{2}{*}{$q[\mathrm{kN} / \mathrm{m}]$} \\
\cline { 4 - 5 } & & & $u_{\min }[\mathrm{mm}]$ & $q_{l}=K_{e}^{q} u_{\min }[\mathrm{kN} / \mathrm{m}]$ & \\
\hline 0.732 & $1.0 \cdot 4.597$ & 0.073 & 6.70 & 30.79 & 18.70 \\
\hline 1.088 & $1.0 \cdot 1.093$ & 0.019 & 12.85 & 14.05 & 7.88 \\
\hline 1.572 & $1.0 \cdot 0.325$ & 0.060 & 12.05 & 3.92 & 3.88 \\
\hline 2.072 & $1.0 \cdot 0.115$ & 0.046 & 31.11 & 3.56 & 2.33 \\
\hline 2.572 & $1.0 \cdot 0.0425$ & 0.032 & 48.85 & 2.08 & 1.69 \\
\hline 3.072 & $1.0 \cdot 0.0279$ & 0.026 & 55.29 & 1.54 & 1.16 \\
\hline
\end{tabular}

\section{NUMERICAL MODELS OF LEDGERS}

\subsection{SELECTION OF THE LEDGER-STAND JOINT MODEL}

The selection of the numerical beam model with a ledger-stand joint is conducted on the basis of static work and research on o-ledgers loaded with a concentrated force. The static work of the pipe element, the main part of the o-ledger in an elastic state, is defined by known formulae of structural mechanics. The problems with modelling an o-ledger as an element of complete scaffold structure occur near to its connection to a stand. This joint works as a flexible connection, but due to the complicated shape of connecting elements (Fig.2c) - including parts of varying stiffness, such as the pipe-end joint, the part of the ledger end connected to a plate, as well as the offset of the ledger end-plate joint from the axis of stand - standard [4] recommends selecting the stiffness on the basis of laboratory testing.

a)

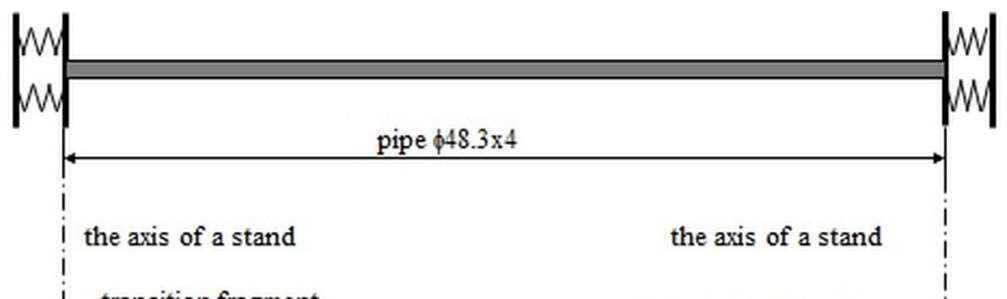

b)

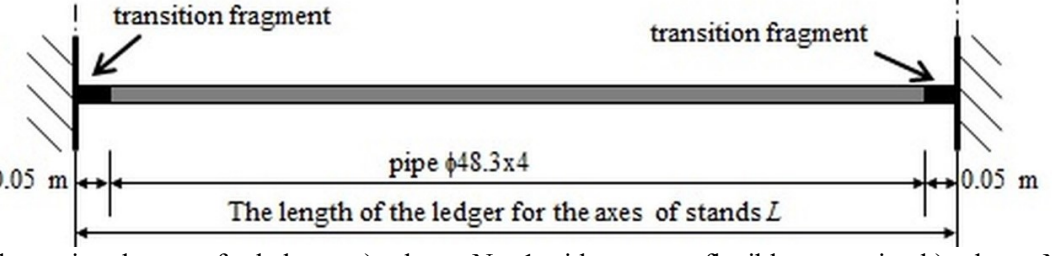

Fig. 4. The static schemes of o-ledgers: a) scheme No. 1 with supports flexible to rotation b) scheme No. 2 with rigid supports and flexibility provided by transition fragments. 
Joint flexibility is modelled via two approaches: a typical modelling of flexible support (Fig. 4a) and an insertion of a transition fragment of $l=5 \mathrm{~cm}$ (Fig. 4b). Joint stiffness $K_{\varphi 1}$ in scheme No. 1 (Fig. 4a) is determined on the basis of displacements obtained from the formula:

$$
K_{\varphi 1}=E J \frac{16 M_{o}}{L^{2}-8 L M_{o}}
$$

where:

$$
M_{o}=\frac{L^{3}-48 \bar{u} E J}{6 L^{2}}
$$

and $E=7 \cdot 10^{7} \mathrm{kPa}$ - Young's modulus for aluminium, $J=13.7676 \cdot 10^{-8} \mathrm{~m}^{4}-$ moment of inertia, $u$ - average displacement at load $F=1.0 \mathrm{kN}$.

Eq. (3.1) and (3.2) are introduced by the force method according to the principles of structural mechanics in reference to a beam with flexible supports on the both ends, and loaded in its midspan with a concentrated force $F=1.0 \mathrm{kN}$. The formulae for scheme No. 2 can be determined similarly, but their development is quite problematic. For this reason, the relationship between joint stiffness $K_{\varphi_{2}}$ and displacement $u$ is determined in a simpler way. A numerical model using static scheme No. 2 is prepared for each ledger. Then, static linear calculations are performed for all lengths of the ledger at 6 different values of joint stiffness $K_{\varphi 2}$ and at a concentrated force $F=1.0 \mathrm{kN}$. The middle part of the ledger, an aluminium pipe of a cross-section $\phi 48.3 \times 4 \mathrm{~mm}$, is modelled by a beam element of the following material characteristics: Young's modulus $E=7 \cdot 10^{7} \mathrm{kPa}$ and density $2.7 \mathrm{t} / \mathrm{m}^{3}$, as well as the following geometrical characteristics: cross-section area $A=5.5669 \mathrm{~cm}^{2}$ and moments of inertia $J=J_{2}=J_{3}=13.7676 \mathrm{~cm}^{4}$. In reference to transition fragments, the following values are assumed: Young's modulus $E=2 \cdot 10^{8} \mathrm{kPa}$, density $7.85 \mathrm{t} / \mathrm{m}^{3}$, and cross-section area $A=5.5669 \mathrm{~cm}^{2}$. The moments of inertia are calculated for every stiffness value based on the formula:

$$
J=K_{\varphi 2} l / E
$$

The results of these calculations are summarized in Fig. 5. Subsequently, on the basis of these results, the functions are determined for each ledger, describing the relationship between joint stiffness and displacement, in the following formula:

$$
K_{\varphi 2}(u)=d+\frac{b}{u-a},
$$

where: $u$-displacement in mm, $a, b$ and $d$-curve coefficients. 


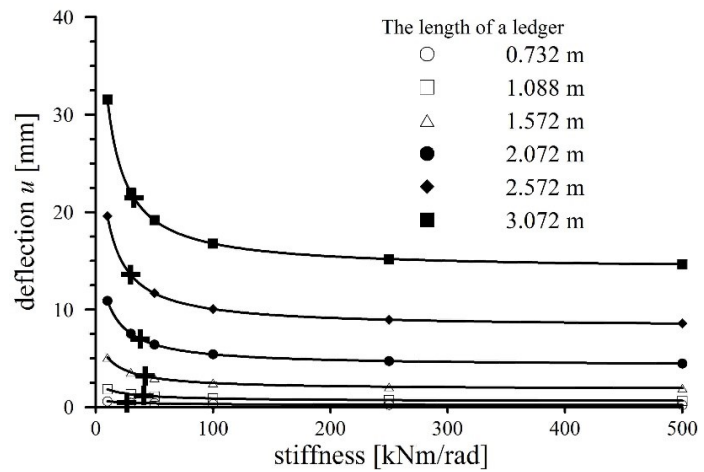

Fig. 5 The graphs of the deflection depending on joint stiffness $K_{\varphi 2},+$ the location of research results.

The parameters of these functions are compiled in Table 4. Using them and the displacements obtained at a concentrated force equal to $1.0 \mathrm{kN}$, the stiffness of connection $K_{\varphi 1}$ is calculated. The value of force is determined as the inverse value of element stiffness $K_{e}$ from Table 2 . The values of joints stiffness, obtained for both schemes, are listed in Table 4 . The last row of Table 4 presents the average values of stiffness $\bar{K}_{\varphi 1}$ and $\bar{K}_{\varphi 2}$ which are in the end assumed as the stiffness which can be used in a numerical model of the scaffold.

Table 4. The curve parameters from Fig. 5 and final properties of elements modelling ledgers ends.

\begin{tabular}{|c|c|c|c|c|c|c|c|}
\hline \multicolumn{2}{|c|}{} & Scheme No. 1 & \multicolumn{5}{|c|}{ Scheme No. 2 } \\
\hline$L[\mathrm{~m}]$ & $\pi=\frac{1 \mathrm{kN}}{K_{e}^{F}}[\mathrm{~mm}]$ & $K_{\varphi 1}\left[\frac{\mathrm{kNm}}{\mathrm{rad}}\right]$ & $a[\mathrm{~mm}]$ & $b\left[\mathrm{~mm} \frac{\mathrm{kNm}}{\mathrm{rad}}\right]$ & $d\left[\frac{\mathrm{kNm}}{\mathrm{rad}}\right]$ & $K_{\varphi 2}\left[\frac{\mathrm{kNm}}{\mathrm{rad}}\right]$ & $J\left[\mathrm{~cm}^{4}\right]$ \\
\hline 0.732 & 0.485 & 34.90 & 0.1766 & 18.4464 & -33.4310 & 26.30 & 0.6576 \\
\hline 1.088 & 1.198 & 56.04 & 0.5870 & 36.6685 & -19.2596 & 40.79 & 1.0199 \\
\hline 1.572 & 3.195 & 58.23 & 1.8069 & 76.3660 & -13.0380 & 41.98 & 1.0495 \\
\hline 2.072 & 6.993 & 52.08 & 4.2192 & 132.1714 & -9.7550 & 37.89 & 0.9474 \\
\hline 2.572 & 13.605 & 39.38 & 8.1829 & 202.8725 & -7.7887 & 29.62 & 0.7406 \\
\hline 3.072 & 21.459 & 44.65 & 14.0767 & 288.2992 & -6.4808 & 32.57 & 0.8143 \\
\hline & & $\bar{K}_{\varphi 1}=\mathbf{3 4 . 8 6}$ & & & & $\bar{K}_{\varphi 2}=\mathbf{4 7 . 5 5}$ & \\
\hline
\end{tabular}

\subsection{THE VERIFICATION OF LEDGER-STAND JOINT SELECTION}

The verification of parameters $\bar{K}_{\varphi 1}$ and $\bar{K}_{\varphi 2}$, presented in Table 4, consists of comparing the measurement results of the displacements in the mid-span of the ledgers with the corresponding values from obtained calculations. The comparisons are performed for o-ledgers, which are subjected to an evenly distributed load, and double o-ledgers, which are loaded with concentrated force applied to the mid-span. These comparisons are demonstrated in Fig. 6. As it can be seen for both cases, the values obtained from measurements and calculations where both schemes are used 
are close to each other. This means that in this type of calculations a single value of joint flexibility can be applied for all ledgers.
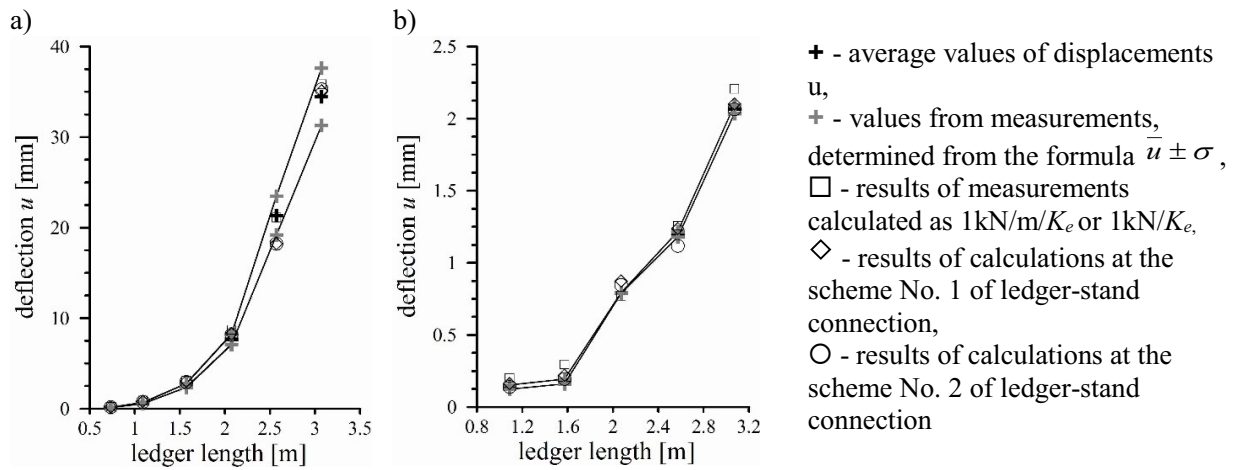

Fig. 6. The comparison of deflections obtained from calculations and measurements for: a) o-ledger at a distributed load $q=1.0 \mathrm{kN} / \mathrm{m}, \mathrm{b}$ ) double o-ledger at a concentrated force $F=1.0 \mathrm{kN}$.

Utilizing the procedure presented in the previous point it should be considered that $k_{i}$ parameters of connections cannot be determined based on fragments of measurement results representing the relationship between the load and displacement which are too short. This can occur when the first points of the measurements line up along a straight-line, and the next ones deviate slightly due to various disturbances of measurements. It is sufficient for function $g_{3}(u)$ to assume greater values for the first several measurements than for the greater group of measured points, constituting a more widely represented group. An example can be seen in Fig. 3; the first maximum in the graph is below $2 \mathrm{~mm}$, and the following ones which can be considered correct, are those above $7 \mathrm{~mm}$. These second maxima are the basis for determining $u_{l}$ for an o-ledger measuring $1.088 \mathrm{~m}$. This approach is also justified by values $u$, obtained for ledgers of similar values for which there are no interpretative problems due to the occurrence of two maxima in the graph $g_{3}(u)$. As seen in Table 2, due to such an approach, an increase in the value of displacement along with an increase of ledger length can be obtained.

\section{Conclusions}

This paper demonstrates two ways of modelling a stand-ledger joint as well as appropriate parameters of these models. The ledger-stand connection is a system of complicated geometry, thus the system components cannot be directly modelled. However, on the basis of the performed 
research, it is stated that both methods of joint modelling proposed in the article can be used and that selected parameters can be applied in engineering practices.

Furthermore, a linear-elastic model can be applied to model the ledger composite material. Load values ending the application ranges of these models are greater than the specified permissible load of the element, in the case of o-ledgers. This means that these values cannot be exceeded, which results in limited possibilities of function beyond a linear-elastic range of element work. Nevertheless, in the case of double ledgers, the force - defining load-bearing capacity - is greater than the force ending the linear range of the work. For this reason, in future research, the influence of this second value needs to be taken into consideration, as it may very well have an impact on load-bearing capacity.

\section{REFERENCES}

1. R.G. Beale, "Scaffold research - A review", Journal of Constructional Steel Research 98: 188-200, 2014.

2. E.Błazik-Borowa, A. Borowa, A. Robak, M. Pieńko, "The choice of function set for laboratory tests results of scaffolding components", The proc. of XXIX Conf. Problems of Development Working Machines, Poland, 2015, in polish.

3. D. Concepcion, M. Pascual, V. Mariano, M.Q. Osvaldo, "Review on the modelling of joint behavior in steel frames", Journal of Constructional Steel Research 67: 741-758, 2011.

4. EN 12811-3:2003: Temporary works equipment - Part 3: Load testing.

5. Feng Fu, Dennis Lam, Jianqiao Ye, "Parametric study of semi-rigid composite connections with 3-D finite element approach", Engineering Structures 29: 888-898, 2007.

6. M. A. Gizejowski, W. Barcewicz, W. Salah, "Finite Element Modelling of the Behaviour of a Certain Class Oof Composite Steel-Concrete Beam-To-Column Joints", Archives Of Civil Engineering LVI, 1: 19-56, 2010.

7. Hongbo Liu, Li Jia, Suolin Wen, Qun Liu, Gang Wang, Zhihua Chen, "Experimental and theoretical studies on the stability of steel tube-coupler scaffolds with different connection joints", Engineering Structures 106: 80-95, 2016.

8. M. Javad Haji Rajabi, M. Saeed Karimi, M. Ali Kafi, "A new model for beam rigid connection to double I-shaped column's web", Journal of Constructional Steel Research 127: 204-220, 2016.

9. E. S. Kameshki, M. P. Saka, "Optimum design of nonlinear steel frames with semi-rigid connections using a genetic algorithm”, Computers and Structures 79: 1593-1604, 2001.

10. A. Kozłowski, "A Review of Models of Semi-Rigid Steel Column-Beam Connections", Archives of Civil Engineering vol. XLII, issue 1: 65-82, 1996.

11. A. Misztela, "Influence of Process Parameters on the Results of Numerical Analysis of Nonlinear Computational Scaffolding", International Journal of Applied Mechanics and Engineering vol.17 (3): 931-940, 2012.

12. Li Jia, Hongbo Liu, Zhihua Chen, Qun Liu, SuolinWen, "Mechanical properties of right-angle couplers in steel tube-coupler scaffolds", Journal of Constructional Steel Research 125: 43-60, 2016.

13. M. Pieńko, A. Robak, E. Błazik-Borowa, "Scaffoldings Used During the Renovation of The Metropolitan Cathedral of St. John the Baptist and St. John the Evangelist In Lublin, Civil And Environ. Eng. Rep. 19(4): 79-86, 2015.

14. M. Pieńko, A. Robak, Stand for testing deformation of horizontal elements evenly loaded, Patent No. (11) 222699 (21) 410025, Wiadomości Urzędu Patentowego 8: 2221, 2016.

15. U. Prabhakaran, R. G. Beale, M. H. R. Godley, "Analysis of scaffolds with connections containing looseness", Computers and Structures 89: 1944-1955, 2011.

16. A. Robak, M. Pieńko, E. Błazik-Borowa, "Examples of unusual construction scaffoldings used for renovation works of historic buildings", Civil And Environmental Engineering Reports 18(3): 115-120, 2015.

17. A. Saritas, A. Koseoglu, "Distributed inelasticity planar frame element with localized semi-rigid connections for nonlinear analysis of steel structures", International Journal of Mechanical Sciences 96-97: 216-231, 2015.

18. Tayakorn Chandrangsu, Kim J.R. Rasmussen, "Investigation of geometric imperfections and joint stiffness of support scaffold systems”, Journal of Constructional Steel Research 67: 576-584, 2011. 


\section{LIST OF FIGURES AND TABLES}

Fig. 1. The scheme of stand-up for measurements of the load-displacement at load by: a) concentrated force, b) uniformly distributed load.

Rys. 1. Schemat stanowisk badawczych do pomiaru zależności siła-przemieszczenie przy obciążeniu: a) siłą skupioną, b) obciążeniem ciągłym.

Fig. 2. The test stand-up for measurements of the load-displacement: a) o-ledger, b) double o-ledger, c) connection of the ledger and stand.

Rys. 2. Stanowisko do pomiaru zależności obciążenie-przemieszczenie dla: a) o-rygla, b)o- rygla podwójnego, c) połączenie rygiel i stojak.

Fig. 3. The measurements results of force versus displacement for: a) the o-ledger with the length of $1.572 \mathrm{~m}$ loaded with concentrated force $F, \mathrm{~b}$ ) the o-ledger with the length of $2.572 \mathrm{~m}$ loaded with uniformly distributed load $q, \mathrm{c})$ the functions $g_{3}(u)$ for o-ledger with length of $1.088 \mathrm{~m}$.

Rys. 3. Wyniki pomiarów zależności siła i przemieszczenie dla: a) o-rygli o długości $1.572 \mathrm{~m}$ przy obiążeniu siłą skupioną $F$, b) o-rygla o długości $2.572 \mathrm{~m}$ obciążeniem ciągłym $q$, c) funkcja $g_{3}(u)$ dla o-rygla o długości $1.088 \mathrm{~m}$.

Fig. 4. The static schemes of o-ledgers: a) scheme No. 1 with supports flexible to rotation b) scheme No. 2 with stiff supports and flexibility provided by transition fragments.

Rys. 4. Schematy statyczne o-rygli: a) schemat $\mathrm{nr} 1 \mathrm{z}$ podporami podatnymi na obrót, b) schemat nr $2 \mathrm{z}$ podporami sztywnymi i podatnością zapewnioną za pomocą fragmentów przejściowych.

Fig. 5. The graphs of displacement depending on joint stiffness $K_{\varphi 2},+$ the location of research results.

Rys.5. Wykresy ugięcia w zależności od sztywności połączenia $K_{\varphi 2},+$ umiejscowienie wyników badań.

Fig. 6. The results comparison between calculations and measurements of ledgers displacements in a midspan a) in reference to o-ledger at a continuous load $q=1.0 \mathrm{kN} / \mathrm{m}, \mathrm{b}$ ) in reference to a double o-ledger at loading by a concentrated force $F=1.0 \mathrm{kN}$.

Rys. 6. Porównanie wyników obliczeń i pomiarów ugięcia rygli w środku rozpiętości w odniesieniu do: a) orygla przy obciążeniu ciągłym $q=1.0 \mathrm{kN} / \mathrm{m}$, b) o-rygla podwójnego przy obciążeniu siłą skupioną $F=1.0 \mathrm{kN}$.

Tab. 1. The summary of o-ledgers types and test types.

Tab. 1. Zestawienie typów o-rygli i rodzajów pomiarów.

Tab. 2. The measurements results of displacements in an elastic scope caused by a concentrated force $F$.

Tab. 2. Wyniki pomiarów ugięcia rygli w zakresie sprężystym od siły skupionej $F$.

Tab. 3. The measurements results of displacements in an elastic scope caused by a continuous load $q$.

Tab. 3. Wyniki pomiarów ugięcia o-rygli w zakresie sprężystym od obciążenia ciągłego $q$.

Tab. 4. The curves parameters from Fig. 6 and final properties of elements, modelling ledgers ends.

Tab. 4. Zestawienie parametrów krzywych z Rys. 6 oraz ostateczne własności elementów, modelujących zakończenia rygli. 


\section{ANALIZA POLĄCZENIA RYGLA ZE STOJAKIEM W ALUMINIOWYM RUSZTOWANIU MODULOWYM}

Slowa kluczowe: rusztowanie modułowe, badania laboratoryjne, połączenia podatne, analizy statystyczne, schemat statyczny rygla

\section{STRESZCZENIE:}

Jednym z typów rusztowań budowlanych jest rusztowanie modułowe. Rusztowania tego typu cechują się tym, że są składane z pojedynczych elementów, takich jak podstawki, rygle, stojaki, stężenia i pomosty. Dodatkowo rusztowania te są tak zaprojektowane, aby można było z nich montować konstrukcje przestrzenne o dowolnym kształcie. Pozwala to na budowę rusztowań wokół obiektów o skomplikowanym kształcie, np. obiektów zabytkowych, w obiektach przemysłowych. Obecnie rozwój rusztowań modułowych opiera się na wprowadzaniu aluminium jako materiału do budowy elementów konstrukcji rusztowania. Dzięki zastosowaniu aluminium rusztowanie jest lżejsze niż w przypadku typowych rusztowań stalowych. Jednak z drugiej strony powoduje to problemy technologiczne, polegające na przykład na łączeniu różnych rodzajów materiałów a później na modelowaniu tych połączeń. W przypadku rusztowań aluminiowych należy również zbadać czy można w modelu numerycznym korzystać z materiału liniowo-sprężystego, w jakim zakresie obciążenia i oczywiście tak, jak w każdym rusztowaniu, określić podatność węzłów.

Analiza podatności węzłów, wykonanych z różnych materiałów i użytych w różnych rodzajach konstrukcji, jest obecnie tematem wielu opracowań. Na przykład praca [5] jest poświęcona badaniom komputerowym podatności węzłów stalowo-betonowych. W pracy zaprezentowano modele numeryczne uwzględniające skomplikowaną geometrię połączeń, nieliniowe charakterystyki materiałowe oraz takie zjawiska nieliniowe jak kontakt oraz tarcie pomiędzy łączonymi elementami. Problem podatności węzłów w rusztowaniach budowlanych jest szczególnie ważny. Temu zagadnieniu poświęcono w całości lub częściowo między innymi również takie prace, jak: [1, 12, 18]. Prace [12] i [18] prezentują badania laboratoryjne podatności różnych węzłów rusztowań. Praca [1] jest pracą przeglądową i można tu znaleźć informacje zarówno o badaniach podatności jak i wykorzystaniu wyników tych badań w analizach statycznowytrzymałościowych rusztowań.

W niniejszej pracy została zaprezentowana analiza wyników pomiarów laboratoryjnych ugięcia rygli aluminiowych pod wpływem obciążenia siłą skupioną i obciążeniem ciągłym. Na postawie tych badań określono zakres pracy rygla o charakterze sprężysto-liniowym. Następnie dla tego zakresu pracy przeanalizowano sposób modelowania połączenia stojak-rygiel, a otrzymane wyniki analiz zostały zweryfikowane na podstawie pomiarów ugięć o-rygli od obciążenia ciągłego oraz o-rygli podwójnych przy obciążeniu siłą skupioną. Ta praca wyróżnia się od wcześniej przytoczonych, ponieważ podatność połączenia jest określana na podstawie badań całego rygla a nie jak do tej pory na podstawie badania samego węzła.

Badania laboratoryjne przeprowadzono na prasie wytrzymałościowej Zwick-Roell. Zarówno o-rygle, jak o-rygle podwójne, montowane były do wykonanych ze stali elementów początkowych, które były nakładane na gwintowany trzpień stalowy o średnicy $38 \mathrm{~mm}$. Dzięki temu sztywność elementów pionowych była znacznie większa od sztywności badanego elementu. Obciążenie w postaci siły skupionej było realizowane za pomocą liny stalowej umieszczanej na środku o-rygla. Przyrost obciążenia był sterowany przemieszczeniem i wynosił $5 \mathrm{~mm} / \mathrm{min}$. Ponieważ lina ulegała znacznemu wydłużeniu w trakcie badania, przemieszczenie trawersy rejestrowane przez prasę nie było wiarygodne, dlatego zastosowano dodatkowy czujnik przemieszczeń LVTD. W przypadku badań przy obciążeniu ciągłym 
zastosowano układ zbloczy oraz lin w celu równomiernego rozłożenia obciążenia na długości rygla. Zblocza montowano do sztywnej belki w równych odstępach a liczba zbloczy zależała od długości rygla. Dla obu rodzajów obciążenia zmierzono zależność pomiędzy siłą na trawersie prasy i ugięciem rygli w środku rozpiętości.

Analizę podatności węzła poprzedzono określeniem zakresu przemieszczeń, dla których można przyjąć, że układ pracuje liniowo i opisać zachowanie rygli w tym zakresie, tzn. wyznaczyć równania prostych, aproksymujących wyniki pomiarów w tym obszarze. W związku z tym po analizie wizualnej wyników dokonano aproksymacji pomiarów dwoma funkcjami: funkcją liniową i wielomianem. Zakres liniowy był wybierany na podstawie lokalnych maksimum funkcji $\mathrm{g}_{3}(u)$, która jest opisana wzorem:

$$
g_{3}(u)=2 \frac{\rho_{p}^{2}(u) \rho_{w}^{2}(u)}{\rho_{p}^{2}(u)+\rho_{w}^{2}(u)},
$$

gdzie: $\rho_{p}^{2}(u)$ - kwadrat współczynnika korelacji dla prostej, $\rho_{w}^{2}(u)$ - kwadrat współczynnika korelacji dla wielomianu. Wyznaczenie zachowania się rygli w zakresie liniowo-sprężystym wymaga określenia tangensa kąta nachylenia prostej, opisującej zależność obciążenie (siła $F$ lub obciążenie ciągłe $q=F /(L-0,1 \mathrm{~m})$ ) - przemieszczenie, nazywane w pracy sztywnością elementu $K_{e}$. Obliczenie tej wartości wykonano zgodnie z procedurą podaną w normie [4] dla węzłów.

Dobór prętowego modelu numerycznego połączenia rygiel-stojak wykonano na podstawie badań pracy statycznej orygli pod wpływem obciążenia siłą skupioną. Praca statyczna elementu rurowego, który jest główną częścią o-rygla, w stanie sprężystym jest określona znanymi wzorami mechaniki konstrukcji. Problemy modelowania o-rygla pojedynczego w pełnej konstrukcji rusztowania występują w okolicy jego łączenia ze stojakiem. Połączenie pracuje jako połączenie podatne, ale z powodu skomplikowanego kształtu łączonych elementów, w tym fragmentów o różnej sztywności takich, jak połączenie rura-głownia, fragment głowni połączonej z talerzykiem a także odsunięcie połączenia głownia-talerzyk od osi rury stojaka, norma [4] zaleca dobór sztywności na podstawie badań.

Podatność węzła została zamodelowana dwoma sposobami: poprzez typowe zamodelowanie podpory podatnej (schemat $\mathrm{nr}$ 1) oraz poprzez wprowadzenie elementu przejściowego o długości $l=5,0 \mathrm{~cm}$ (schemat nr 2). Sztywność podpory $K_{\varphi 1}$ w schemacie nr 1 wyprowadzono za pomocą metody sił zgodnie z zasadami mechaniki budowli w odniesieniu do belki zamocowanej $\mathrm{z}$ dwóch stron na podatnych podporach i obciążonej w środku rozpiętości siłą skupioną $F=1,0 \mathrm{kN}$. W odniesieniu do schematu nr 2 zależność pomiędzy sztywnością węzła $K_{\varphi 2}$ a przesunięciem $u$ wyznaczono na podstawie obliczeń przy 6 różnych sztywnościach połączeń $K_{\varphi 2}$ i sile skupionej $F=1, .0 \mathrm{kN}$. Następnie na podstawie tych wyników dla każdego rygla wyznaczono funkcje, które opisały zależność pomiędzy sztywnością połączenia a ugięciem a w kolejnym kroku odczytano sztywność przy ugięciu, otrzymanym w pomiarach laboratoryjnych. Ostatecznie otrzymano następujące wartości sztywności węzła $\bar{K}_{\varphi 1}=34,86 \mathrm{kNm} / \mathrm{rad}$ i $\bar{K}_{\varphi 2}$ $=47,55 \mathrm{kNm} / \mathrm{rad}$, które zostały zweryfikowane na podstawie pomiarów i obliczeń dla o-rygli poddanych obciążeniu ciągłemu i o-rygli podwójnych poddanych działaniu siły skupionej. Ponadto w pracy stwierdzono, że wartości obciążeń, kończące zakresy stosowania tych modeli, są większe niż dopuszczalne obciążenie elementu w przypadku o-rygli. Oznacza to, że nie wolno dopuścić do przekroczenia tych wartości, a więc także nie dojdzie do wyjścia poza liniowosprężysty zakres pracy elementu. Natomiast w przypadku rygli podwójnych siła, określająca nośność, jest większa niż siła kończąca zakres liniowy pracy, dlatego tutaj w przyszłości należałoby się zastanowić czy o nośności nie powinna decydować właśnie ta druga wartość. 